University of South Carolina

Scholar Commons

$6-2002$

\title{
African Diaspora Archaeology in Guadeloupe, French West Indies
}

Kenneth G. Kelly

University of South Carolina - Columbia, kenneth.kelly@sc.edu

Follow this and additional works at: https://scholarcommons.sc.edu/anth_facpub

Part of the Anthropology Commons

\section{Publication Info}

Published in Antiquity, Volume 76, Issue 292, 2002, pages 333-334.

(c) Antiquity 2002, Cambridge University Press.

This Article is brought to you by the Anthropology, Department of at Scholar Commons. It has been accepted for inclusion in Faculty Publications by an authorized administrator of Scholar Commons. For more information, please contact digres@mailbox.sc.edu. 


\title{
African Diaspora archaeology in Guadeloupe, French West Indies
}

\author{
KENNETH G. KELLY*
}

In May 2001 an initial investigation into the archaeology of the African Diaspora was begun in Guadeloupe, French West Indies. In this first concerted effort to identify archaeological remains associated with the living spaces of enslaved Africans in the French West Indies, historical cartographic data was used to identify, locate and facilitate a preliminary survey of village sites associated with 17 th-19th-century plantation sites. Historical archaeological research of this era in Guadeloupe has focused on industrial remains of plantations which remain prominent in the landscape due to their substantial construction, yet the lightly built structures housing enslaved Africans have not endured (Delpuech 2001). It has been amply demonstrated elsewhere in the Caribbean and in North and South America that archaeology can help to elucidate the experiences and adaptations of enslaved Africans.

During the 18th century, the French colonies of the Caribbean were economic powerhouses, with well-developed slave-based plantation economies housing over $50 \%$ of all enslaved Africans in the Caribbean, yet our understanding of the conditions of, and responses to, slavery in the region are based on research from the British colonies. Of the many differences between the colonies, the most important was the French Revolution which engendered enormous social upheavals. In the Caribbean, it led to revolution in St Domingue followed by the establishment of Haït; in Guadeloupe it caused the unprecedented abolition (in 1794) of slavery and its re-establishment eight years later. Here, historical archaeology can contribute to a more complex and nuanced understanding of the social consequences of slavery in the French West Indies.

The goals of the initial research season were: to determine historical sources available for targeting potential sites; to develop a methodology for locating such sites; and to determine whether village sites associated with enslaved Africans were present and intact. While some British possessions have extensive series of maps and plans (Higman 1988), these apparently do not exist for French colonies. There are only a few such maps of Guadeloupe; happily, the Carte des Ingénieurs du Roi (CIR), produced in the 1760 s, is very de- tailed, depicting the entire island and every plantation. Each sugar estate is shown, with individual buildings noted, including industrial works (a symbol shows the presence of windmill, watermill or animal mill). Villages occupied by enslaved Africans appear as collections of individual buildings apparently reflecting the actual village layout. Some are shown as parallel rows of houses on either side of a roadway, some are randomly distributed clusters, while others are orderly villages laid out on a grid pattern. Roads and geographical features are well represented; comparison with modern topographic maps demonstrates a great degree of conservatism in the road network.

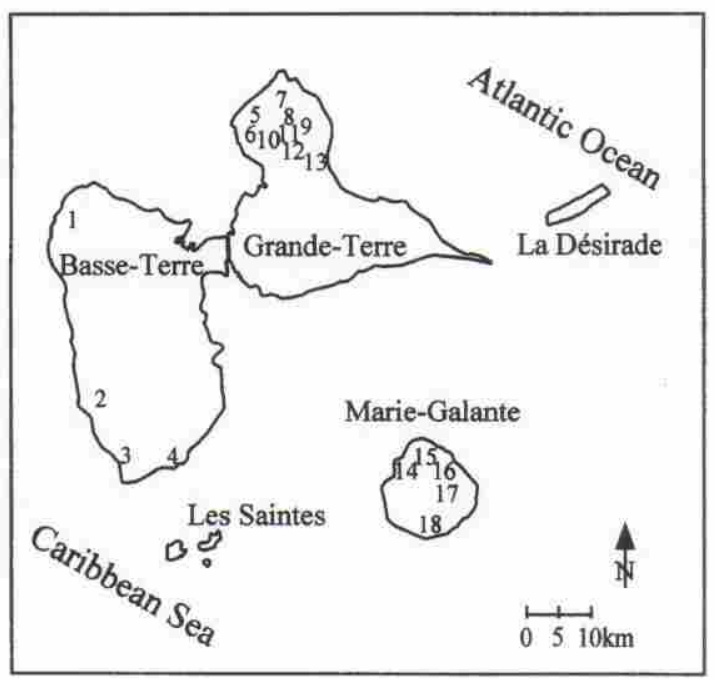

Intact plantation village sites visited on the archipelago of Guadeloupe.

Basse-Terre: 1 Habitation Guyonneau

2 Habitation Géry 3 Habitation Bisdary

4 Habitation Grande Pointe

Grande-Terre: 5 Habitation Coquenda

6 Habitation St Pierre 7 Habitation Le Mercier

8 Habitation Beauvoisin 9 Habitation La Mahaudière 10 Habitation Paviot 11 Habitation Espérance 12 Habitation Pierre Ferraye 13 Habitation Labeth

Marie-Galante: 14 Habitation Grand Pierre 15 Habitation Mayoumbé 16 Habitation Grand Bassin 17 Habitation Boulougne 18 Habitation Murat. 


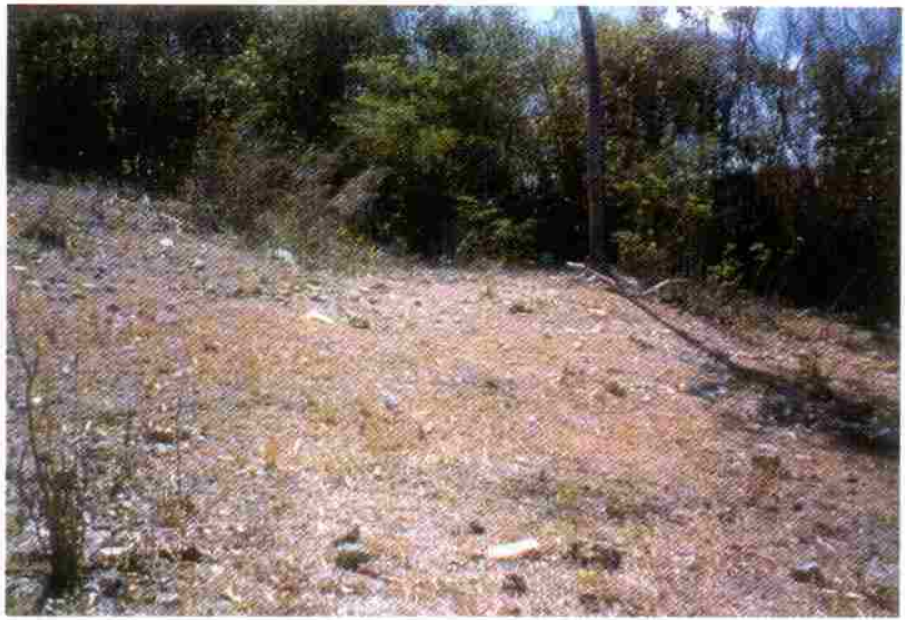

Intact house platform at Habitation Espérance.

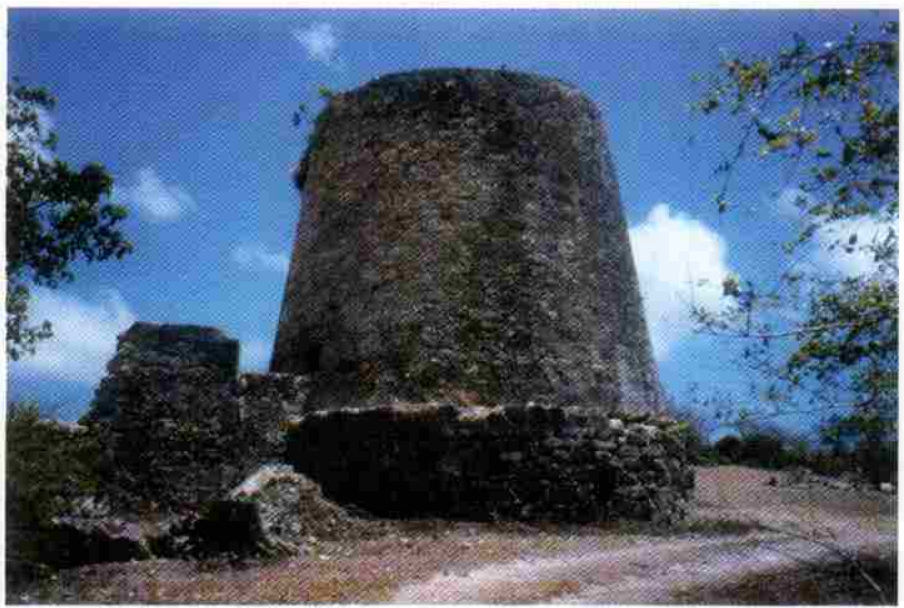

Windmill ruin at Habitation La Mahaudière.

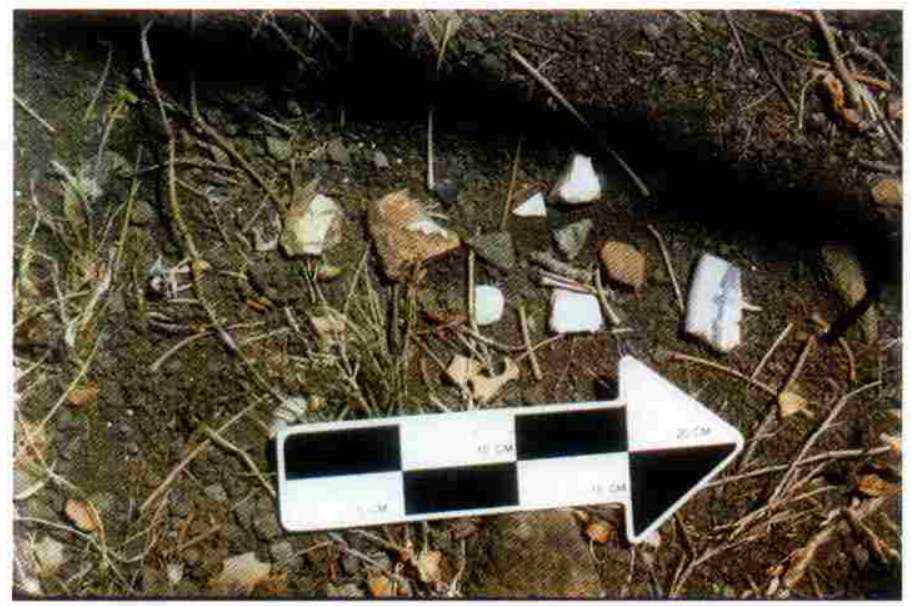

18th-century artefacts at Habitation Guyonneau
Using the CIR in conjunction with modern topographic maps, a number of village sites were selected for field visits; other sites were chosen based upon industrial ruins recorded on modern maps. Features on modern maps not on the CIR were assumed to post-date the $1760 \mathrm{~s}$. Understanding the principles used in situating villages (on hilly or otherwise uncultivable land, reasonably close to the industrial complex, etc.) facilitated prediction of likely landforms; field visits usually confirmed these predictions. Target sites were primarily located in regions of Guadeloupe substantially untouched by rapid urban growth or by banana cultivation.

Nearly 30 village sites were targeted for field visits on Basse-Terre, Grande-Terre and Marie-Galante. Of these about 20 were found to contain features, artefacts or other indications of largely intact village sites. All observations were based on surface artefacts and indications. Most sites dated to mid to late 18th century and early to mid 19th century. Indications at several sites suggest that some villages were abandoned around the end of the 18th century, probably in the upheavals associated with the French Revolution and the abolition of slavery. Archaeological excavation will refine the chronology, permitting a better understanding of the sequence of events.

The results of this initial survey were very promising, suggesting that these largely intact village sites will yield archaeological data to substantively influence our understanding of the nature of French colonial slavery.

\section{References}

DELPUECH, A. 2001. Historical archaeology in the French West Indies: recent research in Guadeloupe, in P.

Farnsworth (ed.), Island lives: historical archaeologies of the Caribbean: 21-59. Tuscaloosa (AL): University of Alabama Press.

HIGMAN, B.W. 1988. Jamaica surveyed: plantation maps and plans of the eighteenth and nineteenth centuries. Kingston: Institute of Jamaica Publications. 